\title{
Of integration and disintegration: The "hows" and "whys" of lifelong learning in a rapidly changing world
}

\author{
Stephen Roche ${ }^{1}$
}

Published online: 25 November 2015

(C) Springer Science+Business Media Dordrecht and UNESCO Institute for Lifelong Learning 2015

\section{Introduction IRE 61:5}

Not since the Second World War has Europe been as preoccupied by the issue of migration as it is today. Almost forgotten are the economic woes of Greece and the crisis of the single currency. For now, Europe has only one crisis to consider. Yet amidst the understandable concern, it is well to remember that migration has always been part of the European experience. And nor do we have to go back to the Völkerwanderung or Great Migration ${ }^{1}$ of the early Middle Ages for evidence of this. Between 1850 and 1913, an estimated 40 million Europeans left their continent to settle in the Americas (Hatton and Williamson 1992). During the same period, several million more partook of various colonial and imperial enterprises overseas. It is easily forgotten that small countries like Ireland and Norway, today among the most prosperous in Europe, were once unable to assure even the bare subsistence of their peoples (Fisher 2014). The nineteenth and twentieth centuries also witnessed a level of internal migration that matches today's. Germany, at the forefront of the debate about the latest wave of migration, absorbed well over a million Polish workers during its rapid industrialisation in the late nineteenth century. Following the First and Second World Wars, this country also took in many more million ethnic German refugees from Eastern Europe (Bundeszentrale für politische Bildung 2015).

It is hard to argue that there is no room in Europe for migrants. As of 2013 not a single member state of the European Union (EU) had a fertility rate at replacement

\footnotetext{
${ }^{1}$ Large population movement, mostly from Asia and Eastern Europe to Western Europe, that accompanied and hastened the demise of the Roman Empire.
}

Stephen Roche

s.roche@unesco.org

1 UNESCO Institute for Lifelong Learning, Hamburg, Germany 
level, and some, like Greece, Spain and Italy, had fallen well below it (Eurostat 2015). Thus, an influx of new migrants may be precisely what is needed to defuse Europe's demographic time bomb. Yet a perception persists among many that Occidental order and prosperity are mortally threatened by a million or so refugees from Syria, the Balkans and Africa. Much of the angst surrounding the current wave of migration concerns the ability of Europe's social welfare and education systems to cope with the newcomers, and the capacity of labour markets to absorb them. It is clear that an influx of workers with a wide spectrum of skills profiles presents challenges, yet the challenges associated with an inverted demographic pyramid, such as that presently facing Japan, are likely to be far greater (Traphagan 2013).

Some of the groundwork required to accommodate migrants has already been done, even if European immigration policies remain highly differentiated and frequently restrictive (Cossarini 2011). This includes removal of barriers to mobility of labour, better recognition of foreign qualifications, and improved access to education and training for adults (Krieger 2011). An important component of the latter is, of course, the recognition, validation and accreditation (RVA) of prior learning, which facilitates the entry into education, employment and training of those who gained skills in non-formal or informal contexts, or in the case of many migrants, in formal contexts not recognised locally. Richard Wanner has argued that recognition of foreign qualifications and prior work experience is "the central immigration issue of the new century [...] in all post-industrial societies receiving immigrants" (Wanner 2001, p. 417), as this affects both immigrants' employment chances and their social integration. The first article of this issue analyses how European recognition and validation mechanisms have included and accommodated migrants. Globally, Europe has been at the forefront in developing RVA systems and national qualifications frameworks (NQFs). The value of this policy was stated explicitly in a 2012 EU recommendation on the validation of non-formal and informal learning: "The validation of learning outcomes [...] can play an important role in enhancing employability and mobility, as well as increasing motivation for lifelong learning, particularly in the case of the socio-economically disadvantaged or the low-qualified." (Council of the European Union 2012, p. 1).

In their paper entitled "Migration and validation of non-formal and informal learning in Europe: Inclusion, exclusion or polarisation in the recognition of skills?" Manuel Souto-Otero and Ernesto Villalba-Garcia first review two divergent strands of literature: theories of consensus and conflict as they relate to migration and immigration regimes; and the literature on validation practices and policies. The authors identify patterns of convergence and divergence in how different European countries approach RVA for immigrants (they broadly group these countries into four models, corresponding to liberal, conservative, universalist and ad-hoc approaches). Second, they explore whether immigrants constitute a dominant user group within those RVA systems, and finally appraise outcomes in terms of inclusion or exclusion. The data employed in this study were drawn largely from the 2014 European Inventory on validation of non-formal and informal learning project, which collated data from 33 European countries. The findings suggest that in the majority of EU countries, immigrants are not widely availing of RVA. Other groups, such as unemployed or young people, are more dominant, and while some 
initiatives targeting immigrants do exist, these tend to be project-based and shortterm, and are more often tailored to highly skilled immigrants.

Many countries grapple with a legacy of institutionalised injustice and exclusion of a particular ethnic, linguistic or socio-economic minority, and look to education and training as a means to level the playing field. However, few face a challenge as daunting as that of South Africa, where for centuries under colonialism and the ensuing policy of apartheid, the large majority of the population was excluded from educational and professional opportunity and relegated to the status of second- and third-class citizens (if the term citizen may even be used in such a context). Following the advent of democracy in that country in 1994, much hope was invested in the potential of the education and training system to reduce poverty and enhance social mobility among the previously oppressed majority. Adult non-formal education and training (NFET) is of particular relevance in this regard, as it attempts to correct the legacy of injustice and exclusion among those who grew up under apartheid or in its immediate aftermath. The South African NFET system was conceptualised as a bridge between formal and informal education, as complementary to the formal system but without the provision of formal certification.

Rather than examine the system as a whole, the authors of our next paper, Celestin Mayombe and Antoinette Lombard, focus on the "enabling environments" of NFET centres; the internal factors which create conditions conducive to skills acquisition. Entitled "How useful are skills acquired at adult non-formal education and training centres for finding employment in South Africa?", this article investigates the extent to which adult NFET centres in KwaZulu-Natal contribute to skills acquisition and employment. They chose to focus on one of the three poorest provinces in South Africa. Poverty in South Africa is still starkly determined by skin colour. A 2008 study indicated the prevalence of poverty (based on the South African government's own indicators) among the "races" of South Africa as $54.8 \%$ for Black Africans, $34.2 \%$ for Coloureds, $7.1 \%$ for Indians and $0.4 \%$ for Whites (Armstrong et al. 2008). The aim of NFET centres is to break the cycle of poverty by providing training in skills likely to enhance employability. This study investigates which conditions inside NFET centres ("internal enabling environments") are most conducive to achieving that aim. The authors found that centres focusing on activities suitable for self-employment during training were more likely to create internal enabling environments for skills acquisition and income generation than centres offering courses designed for entering paid employment. The authors found a significant correlation between NFET centres' training programme objectives, financial resources, trainee selection criteria, the process of training needs assessment, and skills acquisition for successful employment outcomes of NFET graduates. Without these internal enabling factors, adult trainees are likely to continue finding it difficult to enter the labour market or participate in economic activities and hence break the cycle of poverty and social exclusion.

Just as mobile information technology (IT) has allowed many developing countries to "leapfrog" previous phases of information technology (with some surprising results; for example, the number of mobile phone subscriptions per person is higher in Ghana than in Belgium, and internet usage more widespread in 
Oman than in Italy [ITU 2015]), the lifelong learning paradigm has the potential to help countries achieve a similar great leap forward in terms of education and training. In his paper entitled "Lifelong learning as an instrument for human capital development in Benin", Idowu Biao considers the role that lifelong learning can play in developing the "human capital" of this small West African country. This paper reviews Benin's current education system and proposes an alternative system of education based on the concept of lifelong learning. The author begins by detailing the evolution of the educational landscape of Benin since the country won its independence from France in 1960. Benin has emerged as one of the (moderate) success stories of the Education for All (EFA) process, achieving relatively high scores on a number of indicators, including primary school enrolment, gender parity and education spending, albeit starting from a low baseline (UNESCO 2015), yet as the author notes, "each nation must approach the running of [the school system] with circumspection and full understanding of its characteristics and limitations."

Like most countries of sub-Saharan Africa, Benin enjoys the blessing or suffers the curse (depending on perspective) of a very young and rapidly growing population. This country has seen its population expand from 2.4 million to 11 million since independence. Had the United States experienced a commensurate boom, its population today would exceed 800 million. Moreover, $61 \%$ of Beninese are aged between 15 and 50, the most economically productive age group. A young population is a boon if highly skilled and able to enter a mature and diverse labour market, but when many leave school with few basic skills and fewer prospects of employment, the result is a vicious cycle of poverty and economic torpor. The author proposes a re-adjustment of the education system in Benin, based on eight key priorities: provision of universal basic education; expansion of the out-of-school vocational training for both high school and university graduates; entrepreneurship training; computer literacy; liberal education; life-wide and life-deep education; involvement of non-governmental organisations, civil society and public-private partnerships; and international partnerships. Ultimately, in the words of the author, "the freeing up of human capital through the provision of numerous alternative routes to productive engagements is a wise way of guaranteeing peace in society and securing the stability of national governments."

Lifelong learning, adult education and non-formal education have vital roles to play in promoting social inclusion and access to 21 st-century skills, not only in developing countries such as Benin, but also in highly developed economies such as the Netherlands. A well funded school system and a technologised economy are no antidotes to social exclusion. In fact, most of the world's wealthier societies have seen a considerable widening of the gap between rich and poor over the last two decades, to the point where political stability and economic prosperity are threatened as the middle class in many countries of the Global North shrinks (Wang et al. 2014). The Belém Framework for Action (BFA), a set of policy recommendations that emerged from the Sixth International Conference on Adult Education (CONFINTEA VI) in 2009, strongly urged governments to invest in adult education as a means of combating social exclusion (UIL 2010). Yet adult education remains a hard sell for many governments (UIL 2013). There is a perception among those who hold the purse strings of education (governments, NGOs and 
international donors) that a dollar invested in the education of a child yields a higher return than that invested in an adult. This perception is bolstered by arguments that the results of adult education are harder to measure, that adults do not register the same progress in acquiring basic skills, and, perhaps between the lines, that adults are less deserving than children. There is no shortage of arguments to counter the fallacy of this investment 'choice'. We can begin by reminding ourselves that adults and children do not constitute discrete socio-economic groups, and every national and international school performance study confirms that children who grow up in literate homes perform best at school. But perhaps the best argument for investing in adult education is made by reversing the imperative; by asking ourselves to consider the high costs - in terms of, for example, health, crime, childcare and lost economic potential - of not investing in adult education (Knowland et al. 2014).

The authors of our next paper set out to address what is perhaps the most convincing of the arguments against investing in adult education - that the results are harder to measure, or at least that up to now longitudinal data have not been gathered. In their article entitled "The development and validation of testing materials for literacy, numeracy and digital skills in a Dutch context" a research team composed of Maurice de Greef, Mien Segers, Jan Nijhuis, Jo Fond Lam, Mieke van Groenestijn, Frans van Hoek, Alexander van Deursen, Ella Bohnenn and Marga Tubbing present the results of a study to evaluate four tests for reading, writing, numeracy and digital skills among adult learners, which they developed as part of the Language for Life programme, financed by the Dutch Reading \& Writing Foundation. These four tests represent a first step in the development of a broader instrument to assess the impact of adult education. During the study, 926 course participants at 23 formal and non-formal adult education centres throughout the Netherlands were asked to complete one or more tests. These tests can also be used as a diagnostic instrument, as they show progress during several phases of the learning process. The study validated the testing instruments while also identifying aspects which can be improved. These, and the instruments which are likely to follow, will be of invaluable help not only to professionals in the field of adult education (like teachers and trainers), but also for policymakers in demonstrating the positive impact of adult education.

With civil wars raging in Syria and Yemen, the on-going depredation of ISIS, Palestine on the verge of a new intifada, and the promise of the Arab Spring all but extinguished, the Middle East and North Africa (MENA) is a region desperately in need of some good news. Thankfully, there is some good news in the field of education. According to Iqbal Farrukh of the World Bank, "if we rank countries by increases in the average number of years of schooling between 1980 and 2010, nine of the top twenty are from the MENA region" (Farrukh 2014). The World Bank directly credits the near-elimination of gender disparities in primary and secondary education with achieving "a significant decline in fertility and infant mortality, as well as a rapid increase in life expectancy" (World Bank 2008, p. xvi). Moreover, the success stories are not confined to the primary and secondary sectors. According to UNESCO, the number of students enrolled in higher education in the Arab States rose by 256\% between 1999 and 2008 (UNESCO 2009). However, the same World Bank report cited above also highlights a disquieting trend: while countries in this 
region perform well on indicators related to enrolment and participation in education, they are failing to build thriving knowledge economies. There is, according to this report, a persistent lack of student-centered learning, competencybased curricula, and focus on critical thinking in MENA countries. One of the results is that knowledge production in these countries continues to fall sharply below other countries at comparable levels of economic development (World Bank 2008).

This issue is taken up by Kamal Abouchedid and George Abdelnour in their paper entitled "Faculty research productivity in six Arab countries". The authors analyse the research output of a sample of higher education institutions (HEIs) in six Arab countries. A questionnaire classifying HEIs was administered to 310 institutions in Lebanon, Qatar, the United Arab Emirates, Morocco, Saudi Arabia and Jordan. The study revealed a lack of capacity of HEIs to provide quality data, raising issues concerning institutional excellence and transparency. Available data were analysed using a number of statistical methods. The findings show that faculty research output in the Arab world is relatively low. While traditional scholarship has focused on institutional factors such as budgetary allocation as one prime determinant of research productivity, this study claims that other factors need to be considered in explaining the low output, with broad implications for policy formulation. These include overall satisfaction levels of academic staff, socialisation of faculty staff members into a research climate, and university mission vis-à-vis academic research. Given the distinct paucity of studies on faculty research productivity in HEIs in the Arab region, this study seeks to bridge this gap in the literature by providing original data and a basis for further research on this topic.

Officially, education policy within the European Union (EU) remains the strict preserve of member states. However, there is evidence that European education policy, following a broader international trend, is increasingly formulated at supranational level. In the final article of this issue, entitled "Les politiques éducatives dans l'Union européenne - d'une approche intergouvernementaliste vers une démarche d'intégration? Enquête auprès de fonctionnaires européens" [Education policies in the European Union - from an intergovernmental approach towards a process of integration? A survey of European officials.], Mihaela-Viorica Rusitoru argues that, at the dawn of the third millennium, educational policies in the EU are gradually shifting from intergovernmentalism to integration. The European Qualifications Framework, the key competencies for lifelong education and training, and the benchmark criteria set out in two European strategies - Lisbon and Europe 2020 - attest to a real change in the field of education policy.

The author supplemented her literature review by conducting interviews with officials from various European institutions, including the Commission, the Parliament and the Council, in order to compare their testimonies to the official discourse on education policies. The qualitative analysis of the interviews reveals that the principles of subsidiarity and neutrality are being gradually replaced de facto by a new policy of integration that is implemented through "legislative workarounds" [contournements législatifs]. In contradiction with the existing legal framework and the official discourse, it would appear that, due to the growing influence of the European Union in education policy, the objective of reaching a 
common education policy in EU Member States could become a reality in the coming decades.

\section{References}

Armstrong, P., et al. (2008). Poverty in South Africa: A profile based on recent household surveys. Stellenbosch Economic Working Papers: 04/08. Cape Town: University of Stellenbosch.

Bundeszentrale für politische Bildung (2015). Dossier: Deutsche Migrationsgeschichte seit 1871. Retrieved 6 November 2015 from http://www.bpb.de/gesellschaft/migration/dossier-migration/ 56355/migration-1871-1950.

Cossarini, P. (2011). Moving borders: European immigration policy and the multidimensional instability of the boundaries. Romanian Journal of European Affairs, 11(3), 25-37.

Council of the European Union (2012). Council Recommendation of 20 December 2012 on the validation of non-formal and informal learning. Resolutions, recommendations and opinions 2012/C 398/01. Official Journal of the European Union. Brussels: Council of the European Union. Retrieved 16 October 2015 from http://eur-lex.europa.eu/legal-content/EN/TXT/PDF/?uri=CELEX:32012H1222 (01)\&from $=\mathrm{EN}$.

Eurostat (2015). Fertility statistics. Retrieved 7 November 2015 from http://ec.europa.eu/eurostat/ statistics-explained/index.php/Fertility_statistics.

Farrukh, I. (2014). The quality of education in MENA: Some good news. Retrieved 10 November 2015 from http://blogs.worldbank.org/arabvoices/quality-education-mena-some-good-news.

Fisher, M. H. (2014). Migration. A world history. Oxford: Oxford University Press.

Hatton, T. J., \& Williamson, J. G. (1992). What drove the mass migrations from Europe in the late nineteenth century? National Bureau of Economic Research Historical Working Paper No. 43. Cambridge, MA: NBER.

ITU (International Telecommunications Union) (2015). Statistics. Retrieved 9 November 2015 from http://www.itu.int/en/ITU-D/Statistics/Pages/stat/default.aspx.

Knowland, V., et al. (2014). Educating the adult brain: How the neuroscience of learning can inform educational policy. International Review of Education, 60(1), 99-122.

Krieger, H. (2011). Optimizing mobility: Europe needs more and better geographical labour mobility. In C. Kusch (Ed.), The internationalization of labour markets (pp. 135-164). Geneva: International Institute for Labour Studies.

Traphagan, J.W. (2013). How demography is changing Japan. Article published in The Diplomat. Retrieved 9 November 2015 from http://thediplomat.com/2013/02/how-demography-is-changingjapan/.

UIL (UNESCO Institute for Lifelong Learning). (2010). Belém Framework for Action: Harnessing the power and potential of adult learning and education for a viable future. Hamburg: UIL.

UIL (2013). Second global report on adult learning and education. Hamburg: UIL.

UNESCO (2015). EFA Global monitoring report. Education for all 2000-2015: Achievements and challenges. Paris: UNESCO.

UNESCO (United Nations Educational, Scientific and Cultural Organization). (2009). A decade of higher education in the Arab States: Achievements \& challenges. Beirut: UNESCO Regional Bureau for Education in the Arab States.

Wang, C., Caminada, K., \& Goudswaard, K. (2014). Income redistribution in 20 countries over time. International Journal of Social Welfare, 23(3), 262-275.

Wanner, R. A. (2001). Diagnosing and preventing "brain waste" in Canada's immigrant population: A synthesis of comments on Reitz. Journal of International Migration and Integration, 2(3), 417-428.

World Bank. (2008). The road not travelled: Educational reform in the Middle East and North Africa. Washington, D.C.: The World Bank. 